\title{
Effect of Liquidity on the Dividend Pay-out by Firms Listed at the Nairobi Securities Exchange, Kenya
}

\author{
Margaret Akinyi Olang, Grace Melissa Akenga, James Kamau Mwangi \\ Department of Business Administration, Chuka University, Chuka, Kenya
}

Email address:

Margaretolang087@gmail.com (M. A. Olang), akengamgrace@gmail.com (G. M. Akenga)

\section{To cite this article:}

Margaret Akinyi Olang, Grace Melissa Akenga, James Kamau Mwangi. Effect of Liquidity on the Dividend Pay-out by Firms Listed at the Nairobi Securities Exchange, Kenya. Science Journal of Business and Management. Vol. 3, No. 5, 2015, pp. 196-208.

doi: $10.11648 /$ j.sjbm.20150305.18

\begin{abstract}
Dividend decision is a critical finance function since it involves determining the amount distributed to shareholders as earnings or the amount to reinvest internally. The determination of dividend pay-out is influenced by the liquidity position of the firm but the extent to which liquidity affects the dividend pay-out still remains a puzzle since most empirical studies conducted have reported inconsistent results and no universally accepted explanation for companies with adequate liquidity have observed uniform dividend payment behaviour. It is in this context that the study was set out to determine the effect of liquidity on dividend pay-out of a firm. The objectives of the study were; to determine the effect of profitability, cash flows and working capital on the firms' dividend pay-out decisions. The study employed causal comparative research design on a target population of 61 firms listed at the NSE. Purposive sampling was used to select 30 firms which consistently paid dividends from the year 2008 to 2012. Data analysis was done using descriptive and inferential statistics. The study revealed that profitability plays a major role in dividend pay-out because of the higher coefficient as compared to cash flows and working capital and consequently the companies which posted higher profits translated this to higher dividends paid out to investors. The study recommends that firms should ensure that profits are stable, cash flows freely flow into the firm and working capital is efficiently managed so as to increase the firms' dividend pay-out. The results would provide information to managers to determine an optimal dividend pay-out that would maximise the company's stock price and thus lead to maximisation of shareholders wealth. The study also forms a basis for further research and adds knowledge to the existing body.
\end{abstract}

Keywords: Cash Flows, Dividend, Liquidity, Dividend Pay-out, Profitability, Securities Exchange, Working Capital, Shareholder

\section{Introduction}

Liquidity of a firm refers to its ability to meet short term obligations using the firm's assets that can be quickly converted to cash since cash is the most liquid form of asset (Bangkok Bank, 2008). Liquidity management entails elimination of default chances on obligations as they fall due and balancing between short term assets and liabilities (Eljelly, 2004). Proper liquidity management is essential in every organization and indicate a business' ability to meet the payment obligations by comparing the cash and near-cash with the payment obligations. If the current assets of the firm are less than the current liabilities, it indicates that the business might face difficulties in meeting its immediate financial obligations. This can, in turn, affect the company's business operations and effectiveness and its ability to pay dividends.
Dividend pay-out is a portion of a company's net profits distributed by the company to a class of its stockholders. The dividend is paid in a fixed amount for each share held. Although most companies make quarterly payments in cash (cheques), dividends also may be in the form of property, scrip, or stock. Scott (2003) observed that, unlike interest on a debt, dividends must be voted on by the company's directors before each payment. Dividend pay-out ratio determines the amount of earnings to be distributed to the shareholders and the amount to be retained in the firm. Dividend pay-out is important in that retained earnings are the most significant and cheap internal source of financing, while on the other hand divided pay-out is a desirable return on investment to the shareholders.

According to Brealey and Myers (2002) dividend pay-out has been kept as the top ten puzzles in finance. The most pertinent question to be answered here is that how much cash 
should firms give back to their shareholders?, Should corporations pay their shareholders through dividends or by repurchasing their shares, which is the least costly form of policy from tax perspective?. Firms must take these important decisions period after period (Black \& Scholes, 1974). Dividend policy connotes to the payment policy, which managers pursue in deciding the size and pattern of cash distribution to shareholders over time. Managements' primary goal is shareholders' wealth maximization, which translates into maximizing the value of the company as measured by the price of the company's common stock. This goal can be achieved by giving the shareholders a "fair" payment on their investments.

Payment of dividends means cash outflow (Pandey, 2005). Although a firm may have adequate earnings to declare dividends it may not have sufficient cash to pay dividends thus the cash position of the firm is an important consideration in paying dividends, the greater the cash position and overall liquidity of a company, the greater will be the ability to pay dividends. Firms face the problem of liquidity even though they make good profits; they continuously need funds for financing growing fixed assets and working capital. Because of the insufficient cash or pressure on liquidity, management may follow a conservative dividend payout policy.

Nairobi Securities Exchange (NSE) is the principal stock exchange of Kenya. It began in 1954 while Kenya was still a British colony, with permission from the London Stock Exchange. The NSE is a member of the African Stock Association. It is Africa $4^{\text {th }}$ largest exchange in terms of trading volumes, and $5^{\text {th }}$ in terms of market capitalization as a percentage of Gross Domestic Product. NSE is licensed by Capital Market Authority (CMA) with its main obligation to regulate the security market and ensure trading of securities by bringing together borrowers and investors at low cost. Regulation of quoted firms is achieved by ensuring that firms stand by the rules and regulations set by providing their periodic performance reports. As a capital market institution, the Stock Exchange plays an important role in the process of economic development. It helps mobilize domestic savings thereby bringing about the reallocation of financial resources from dormant to active agents. Long-term investments are made liquid, as the transfer of securities between shareholders is facilitated. The Exchange has also enabled companies to engage local participation in their equity, thereby giving Kenyans a chance to own shares (NSE, 2009).

The securities exchange is a market that deals in the exchange of securities issued by publicly quoted companies and the Government.The shares of sixty one companies listed at the NSE trade into eleven sectors namely agricultural, automobiles and accessories, banking, commercial, construction and allied, energy and petroleum, insurance, investment, manufacturing and allied, telecommunication and technology and growth and enterprise market, while bonds traded consist of government and corporate bonds (NSE, 2009). The NSE has made tremendous improvements from its inception to date. These include the first privatization done through NSE in 1988, when the government off-loaded $20 \%$ of its shares in Kenya Commercial Bank, In 1996, the largest share issue in the history of NSE, the privatization of Kenya Airways, was successful and in 2006, the NSE trading was fully automated. From these progresses, the NSE becomes a point of attention for studies.

Dividend decisions are among the most important decisions made by finance managers of any firm and are in line with shareholders wealth maximisation goal. These decisions involve determining an optimum dividend pay-out ratio which in turn depends on the liquidity of the firm. Firms with adequate liquidity are more likely to pay higher dividends than firms with lower liquidity. Liquidity has been analyzed as one of the factors affecting the dividend pay-out but the extent to which liquidity affects the dividend pay-out for a firm still remains a puzzle since various empirical studies conducted have produced inconsistent results. Furthermore, no universally accepted explanation for companies with adequate liquidity has observed uniform dividend payment behaviour. From the studies it is noted that researchers have focused mainly on developed markets while little attention has been paid in emerging markets like Kenya. Absence of sufficient evidence on how liquidity impacts on the dividend payout would more likely lead to suboptimal dividend payout decisions. This would impact on the company's stock price and hence affect shareholders wealth maximisation goal. The purpose of the study was to determine the effect of liquidity on the dividend payout by firms listed at the NSE. The study was guided by the following specific objectives;

i. To determine the effect of profitability on the firms' dividend payout decisions.

ii. To determine the effect of cash flows on the firms' dividend payout decisions

iii. To determine the effect of working capital on the firms' dividend payout decisions.

\section{Literature Review}

\subsection{Dividend Theories}

The theories explaining dividend policy are divergent. Some theories argue that dividends are irrelevant while others argue that dividends are relevant.

\subsubsection{Dividend Irrelevance Theories}

The propagators of this theory Modigliani and Miller (1961) stated that the dividend policy employed by a firm does not affect the value of the firm. They argue that the value of the firm is dependent on the firm's earnings which result from its investment policy, such that when the policy is given the dividend payout policy is of no consequence. MM's dividend-irrelevance theory says that investors can affect their return on a stock regardless of the stock's dividend. For example, suppose, from an investor's perspective, that a company's dividend is too big. That investor could then buy more stock with the dividend that is over the investor's expectations. Likewise, if, from an investor's perspective, a company's dividend is too small, an investor could sell some of the company's stock to replicate the cash flow he or she 
expects (Baker \& Wurgler, 2004). As such, the dividend is irrelevant to investors, meaning investors care little about a company's dividend policy since they can simulate their own.

Banarjee (2008) the fact that the trading friction is pervasive in financial markets leads one to believe that the more liquid a stock is, the better, and investors do indeed have a dividend preference based on the liquidity of the stock. Albercht and Stice (2008) advocate for retained earnings over dividends. Retained earnings are profits generated by a company that are not distributed to stockholders (shareholders) as dividends but are either reinvested in the business or kept as a reserve for specific objectives (such as to pay off a debt or purchase a capital asset). Theoretically a company that does not pay dividends should be able to reinvest its earnings in assets that would enable it to grow.

In residual dividend theory a firm will pay dividends from residual earnings i.e. earnings remaining after all suitable projects with positive NPV has been financed. It assumes that retained earnings are the best source of long term capital since it is readily available and cheap. This is because no floatation cash are involved in use of retained earnings to finance new investments. Therefore, the first claim on earnings after tax and preference dividends will be a reserve for financing investments. Dividend policy is irrelevant and treated as passive variable. It will not affect the value of the firm. However, investment decisions will.

Agency Cost and Free Cash Flow Theory by Rozeff (1982) holds that payment of dividend reduces free cash flow available for management to pursue their personal opportunistic consumption and suboptimal investments. Payment of dividend may force management to go to the capital market in order to raise needed capital for investment hence ensuring that only viable projects are undertaken. The company should pay the shareholders profits that rightly belongs to them and let them make their own investment decisions. When a company is controlled by a majority of insiders; there is less need to pay dividends to reduce agency costs. On the contrary, agency cost will become higher when the shareholding structure of a company is dispersed and hence higher dividend policy.

Tax Preference Theory by Litzenberger and Ramaswamy (1979) holds that the tax rate on dividend is higher than the rate on capital gain. A firm that pays dividend will therefore have a lower value since shareholders will pay taxes on this dividend. Under this theory, investors prefer companies that retain earnings and thus provide returns in the form of lower-taxed capital gains rather than higher-taxed dividends. When the effective rate of tax on dividend income is higher than the tax on capital gains, some shareholders, because of their personal tax positions, may prefer a high retention/low pay-out policy. Therefore a firm that pays no dividend has the highest value.

\subsubsection{Dividend Relevance Theories}

These are theories whose propagators argue that the dividend policy of a firm affects the value of the firm. Gordon (1963) in his Bird-in-Hand theory contends that dividend policy affects the value of the firm. He argues that shareholders are risk averse and prefer certainty. Dividends payments are more certain than capital gains which rely on demand and supply forces to determine share prices. Therefore, one bird in hand (certain dividends) is better than two birds in the bush (uncertain capital gains). In this theory "the bird in the hand' is referring to dividends and "the bush" is referring to capital gains. According to this theory, a firm that pays high dividends (certain) will have higher value since shareholders will require using a lower discounting rate. Walter (1963) argues that the choice of dividend policies almost affects the value of the firm. According to this theory, the dividend policy should be determined solely by the profitability of investments. Besley and Brigham (2008) argue that if the main aim of the manager is to maximise the value of the firm, then investors should prefer the firm to pay dividends if investments opportunities do exist.

Al-Malkawi (2007) affirms that firms in their growth stage, which tend to pay lower dividends, would attract clientele that desire capital appreciation, while firms in their maturity stage, which pay higher dividends, attract clientele that require immediate income in the form of dividends. Al-Malkawi (2007) grouped the clientele effect into two groups, those that are driven by tax effects and those driven by transaction cost. He argued that investors in higher tax brackets would prefer firms that pay little or no dividends, to get reward in the form of share price appreciation, and vice versa. Transaction cost-induced clientele, on the other hand, arises when small investors depend on dividend payments for their needs; this clientele prefers companies who satisfy this need because they cannot afford the high transaction cost of selling securities. Therefore, when a firm sets a dividend policy, there'll be shifting of investors into and out of the firm until equilibrium is achieved. Low, income shareholders will shift to firms paying high dividends and high income shareholders to firms paying low dividends.

Agency theory by Ross, Westerfield and Jordan (2011) argued that the agency problem between shareholders and managers can be resolved by paying high dividends. If retention is low, managers are required to raise additional equity capital to finance investment. Each fresh equity issue will expose the managers financing decision to providers of capital e.g. bankers, investors, suppliers etc. Managers will thus engage in activities that are consistent with maximization of shareholders wealth by making full disclosure of their activities. This is because they know the firm will be exposed to external parties through external borrowing. Consequently, Agency costs will be reduced since the firm becomes self-regulating. Baker (2009), Dividend payout policy will have a beneficial effect on the value of the firm. This is because dividend payout policy can be used to reduce agency problem by reducing agency costs. The theory implies that firms adopting high dividend pay-out ratio will have a higher value due to reduced agency costs.

\subsection{Dividend Measures}

According to Ross et al. (2011) dividend is expressed as 
shillings per share (dividend per share), as percentage of market price (dividend yield), as a percentage of the company's profit (earnings per share), or as a percentage of earnings per share (dividend pay-out ratio).

\subsubsection{Dividend Yield}

Dividend yield is a ratio that shows how much a company pays out in dividends each year to its share price (Al-Malkawi, 2007). In the absence of any capital gains, the dividend yield is the return on investment for a stock. Dividend yield measures how much cash flows the firm is getting for each shilling in an equity position.

$$
\text { Dividend yield }=\frac{\text { Dividend per share }}{\text { Market price per share }}
$$

\subsubsection{Dividend Cover}

Dividend cover is a coverage ratio that measures a company's ability to pay off its required dividends payments (Ross et al. 2011). A healthy company will have a high coverage ratio indicating that it has a little difficulty in paying off its dividend. This ratio not only gives the investors an idea of a company's ability to pay dividends requirements but also gives common shareholders an idea on how likely they are to be paid dividends.

$$
\text { Dividend cover }=\frac{\text { Profits after tax }}{\text { Dividend paid }}
$$

\subsubsection{Dividend Payout Ratio}

Dividend payout ratio is the amount of dividends that the stockholders will receive for each share of stock held. A stable dividend payout ratio indicates a solid dividend policy by the company's board of directors. The payout ratio provides an idea of how well earnings support the dividend payments. More mature firms tend to have a higher payout ratio (Pandey, 2005). It's generally a percentage of dividends per shares to earnings per share, and it varies with industry, market conditions and tax law. Moreover, both a low dividend payout ratio and a high dividend payout ratio can have good or bad implications. A low dividend payout ratio can indicate a fast-growing company whose shareholders willingly forego cash dividends, because the company uses the extra money to generate higher returns and, in turn, a high stock price. But also a low dividend payout ratio can also point to a company that simply can't afford to pay dividends. Similarly, a high dividend payout ratio can indicate a blue-chip that pays high dividends and whose stock price is temporarily depressed. Also a high dividend payout ratio can also point to a mature company with few growth opportunities.

$$
\text { Dividend payout ratio }=\frac{\text { Dividend paid }}{\text { Earnings to ordinary shareholders }}
$$

\subsubsection{Earnings per Share}

Earnings per share is the portion of the company's profit after tax that is allocated to each ordinary share (Scott, 2003). It serves as an indicator of the company's profitability and is considered the most important variable in determining a share price.

$$
\text { Earnings per share }=\frac{\text { Earnings attributable to shareholders }}{\text { Number of outstanding Equity }}
$$

\subsection{Liquidity}

Liquidity is the degree to which an asset or security can be bought or sold in the market without affecting the asset price. It is the ability to convert an asset to cash quickly (Pandey, 2005). The fact that the trading friction is pervasive in financial markets leads one to believe that the more liquid a stock is, the better, and investors do indeed have a dividend preference based on the liquidity of the stock (Banarjee, 2008). Stocks that pay dividend satisfy investors need for liquidity. This is even more important for stocks that are thinly traded, for which investors may either have to wait long time for a buyer and/or take a potentially lower price. Liquidity refers to the ease with which an investment asset (stock, bond, and mutual funds) can be converted into cash in a short period of time without a significance decrease in its value (Eljelly, 2004). Although the possibility of a link between liquidity and dividend rates back to Modigliani and Miller (1961) there is a very little direct evidence on the issue. Liquidity is a relatively broad concept which in this case refers to the ability to trade large volumes quickly, at low cost and without moving the price. Liquidity affects the attractiveness of a stock to investors. Investors may require higher expected returns on assets whose returns are sensitive to liquidity.

Local market liquidity is also an important driver of returns in emerging markets (Bekaert et al., 2007). According to Scott (2003) cash flow is a key component in any business. Therefore maintaining solvency and liquidity is important for a business sustainability and growth. A quick and comprehensive way of assessing the business liquidity is through the use of liquidity ratios. Liquidity ratios are used to determine a business's ability to meet its short term financial obligations. These ratios are of particular concerns to both owners and creditors of the business.

According to Pandey (2005) the availability of cash and sound financial position is also an important factor in dividend decisions. A dividend represents a cash outflow, the greater the funds and the liquidity of the firm the better the ability to pay dividend. The liquidity of a firm depends very much on the investment and financial decisions of the firm which in turn determines the rate of expansion and the manner of financing. If cash position is weak, stock dividend will be distributed and if cash position is good, company can distribute the cash dividend. Liquidity is about how big the trade-off is between the speed of the sale and the price it can be sold for. In a liquid market, the trade-off is mild: selling quickly will not reduce the price much (Sharan, 2009). Liquidity affects the dividend policy since the firms paying out dividends must take into consideration the liquidity position of the firm. Cash dividends distribution not only depends on the profitability of a firm but also depends on the free cash flow, which is the amount of operating cash flow left over after payment for capital expenditures. 


\subsubsection{Profitability}

Dividend payment often involve cash outflow (cash dividend are popular) such firms do not wish to issue stock dividends or pay dividend in another form, then dividend payment may be sacrificed due to lack of enough cash thus the cash position of the firm is an important consideration in paying dividends. Profitability is the efficiency of a firm in generating profit and often in the form of ratio. A company's capacity to pay dividend will be determined primarily by its ability to generate adequate and stable profits and cash flow. If the company has liquidity problem, it may be unable to pay cash dividend and result to paying stock dividend. Watson and Head (2007) in their study concluded that a company before paying dividends must consider its liquidity not withstanding high profits. They argued that profits are not the same as cash and therefore the amount of dividends paid must reflect not just the company profits but its ability to pay dividends.

Ross et al. (2011), observed that young and unprofitable firms tend to pay low dividends because of low liquidity, since much of its earnings is taken for investment purposes, but as the firms matures, it begins to generate cash flows beyond that is needed to fund profitable investments and this surplus must be distributed as dividends to shareholders since it may cause agency problems. Watson and Head (2007) explain that a company before paying dividends must consider its liquidity and dispels the notion that a company with high profits can afford high dividends. They noted that profits are not the same as cash and therefore the amount of dividends paid must reflect not just the company profits but its ability to pay dividends.

\subsubsection{Cash Flows}

Cash flow is the amount of operating cash flow left over after payment for capital expenditures. These are revenues or expense streams that changes a cash account over a given period of time. The cash flow of a firm is an important factor in dividend pay-out decisions. A poor inflow of cash means a firm will be constrained to pay generous dividends. Alli, Khan and Ramirez (1993) noted that there was constructive correlation between cash flow and dividend pay-out. Firms also tailor their dividend policies to their long term investment opportunities. For growing firms a substantial amount of funds is required and hence it gives precedence to the retention of earnings over payment of dividends, while for matured firms, investments opportunities occur infrequently and as such may distribute much of their earnings, Based on this, a firm will have to assess its investments opportunities and accompanying financial needs as it endeavours to meet its strategic plans and the firm dividend pay-out.

According to $\mathrm{Liu}$ and $\mathrm{Hu}(2005)$ if the cash dividend is less than the free cash flow, it means the firm has residual cash, if the cash dividend is more than the free cash flow then it means the firm needs financing to meet the requirement of cash dividends. Amidu and Abor (2006) noted that there was positive relationship between cash flow and dividend payout ratios. Anil and Kapoor (2008) also indicated that cash flow is an important determinant of dividend pay-out ratio. Alli et al
(1993) argued that dividend payments depend more on cash flows, which reflect the company's ability to pay dividends, than on current earnings, which are less heavily influenced by accounting practices.

\subsubsection{Working Capital}

Working capital is the difference between current assets and current liabilities. Current assets are the most liquid of your assets, meaning they are cash or can be quickly converted to cash. Current liabilities are any obligations due within one year. Working capital measures what is leftover once you subtract your current liabilities from your current assets, and can be a positive or negative amount. The working capital is available to pay your company's current debts, and represents the cushion or margin of protection you can give your short-term creditors. Positive Working capital is essential for your company to meet its continuous operational needs. According to Weiner (2006) the availability of working capital influences your company's ability to meet its trade and short-term debt obligations, as well as to remain financially viable. If your current assets do not exceed your current liabilities, you run the risk of being unable to pay short term creditors in a timely fashion and as a result not being able to pay dividends. Paying of dividends depends on the management of working capital. A company can be endowed with assets and profitability but short of liquidity if its assets cannot readily be converted into cash.

Operating cycle is the time duration required to convert sales, after the conversion of resources into inventories, into cash. The operating cycle of a company involves the acquisition of resources such as raw materials, manufacture of the product and finally the sale of the product (Pandey, 2005). It equals the time in selling inventories plus the time taken in recovering cash from trade receivables. It is called operating cycle because this process of producing, purchasing inventories, selling them, recovering cash from customers, using that cash to purchase/ produce inventories and so on is repeated as long as the company is in operations. Operating cycle is a measure of the operating efficiency and working capital management of a company. A short operating cycle is good as it tells that the company's cash is tied for a shorter period. The length of the operating cycle of a firm is the sum of inventory conversion period and debtors' conversion period.

\subsection{Liquidity Measures}

According to Pandey (2005) liquidity is expressed as a ratio of current assets to current liabilities (current ratio), as a ratio of current assets less stock to current liabilities (quick ratio), as a ratio of cash and short term marketable securities to current liabilities (cash ratio).

\subsubsection{Current Ratio}

A current ratio is a ratio of current asset to current liabilities. Current ratio is known as working capital ratio and is calculated by dividing total current assets by total current liabilities (Weiner, 2006). A current asset is an asset on the 
statement of financial position which can either be converted to cash or used to pay current liabilities within 12 months. These include; cash, cash equivalent, short term investments, account receivables, inventories and prepayments within a year. A current ratio is frequently used as an indicator of a company's liquidity and ability to meet short term obligations. A current ratio of more than 2:1 means that a business has more current assets than current liabilities thus able to meet its short term obligations. A ratio of less than $2: 1$ indicates that the business is holding more current liabilities than current assets. The most ideal situation should be $2: 1$.

$$
\text { Current ratio }=\frac{\text { Current Assets }}{\text { Current Liabilities }}
$$

\subsubsection{Quick Ratio}

Quick ratio is a ratio of total current assets less stock to total current liabilities. Quick ratio is a liquidity indicator that further refines the current ratio by measuring the amount of the most liquid current assets there are to cover current liabilities (Ross et al. 2011),. It refers to assets that can be quickly converted into cash to meet the liabilities as they fall due. Current liabilities are a company's obligations that are due within one year. Current liabilities appears in a company's statement of financial position and include; short terms debts, accounts payables, accrued liabilities and other debts that fall due within a year. Essentially these are bills that are due to creditors and suppliers within a span of one year. An ideal situation is where the ratio is $1: 1$ thus a higher ratio of more than $1: 1$ is not good for the firm as it will decrease the firms' profitability.

$$
\text { Quick ratio }=\frac{\text { Current Assets-Stock }}{\text { Current Liabilities }}
$$

\subsubsection{Cash Ratio}

Cash ratio is a refinement of the acid test ratio indicating the ability of the firm to meet its current liabilities from its most liquid resources (Pandey, 2005). Short term marketable securities refers to short term investment of the firm which can be converted into cash within a very short period for example commercial paper and treasury bills.

$$
\text { Cash ratio }=\frac{\text { Cash in hand } / \text { bank }+ \text { short term marketable securities }}{\text { Current Liabilities }}
$$

\subsubsection{Net Working Capital Ratio}

Net working capital ratio indicates the proportion of total net assets which is liquid enough to meet the current liabilities of the firm. It is expressed in \% term. Where Net Assets or Capital employed $=$ Total Assets - Current liabilities

$$
\text { Net working capital Ratio }=\frac{\text { Net working capital }}{\text { Net Assets }} * 100 \%
$$

\subsection{Dividend Pay-out}

Dividend refers to the distribution of a portion of a company's earnings to ordinary shareholders decided by the board of directors. Distributions to shareholders may be in the form of cash dividend, stock dividend and property dividend. Cash dividend is the distribution of cash to its common stockholders (Nikolai, Bazley \&Jones, 2010). Stock dividends refers to payment made in the form of additional shares, rather than a cash policy These distributions are generally acknowledged in the form of fractions paid per existing share (Schneeman, 2010). Property dividends refer to the distribution of non cash asset such as land, inventories and equipment to shareholders (Banarjee, 2008). Dividends are commonly defined as the distribution of earnings (past or present) in real assets among the shareholders of the firm in proportion to their ownership.

Dividends are not just an outcome of a firm pay-out policy; they reflect a complicated combination of investment strategy, financial decisions and private information (Miller \& Rock, 1985). From managerial perspective, dividend can serve as a tool to mitigate agency problems by digesting extra free cash flows or to signal to the market that only good quality firms afford to pay dividends (Bhattacharya, 1979). On the other hand from the investor's perspective, dividends are beneficial since they represent a regular income stream which will enhance self control by avoiding any irrational trades (Shefrin \& Statma, 1984). Linter (1956) surveyed corporate chief executive officers and chief financial officers and found that dividend policy is an active decision variable because managers believe that stable dividends lessen negative investors reactions. The active determination of dividend policy implies that the level of retained earnings and savings is a dividend decision by product. Fama and Babiak (1968) find empirical support for Linter's findings; dividend are a function of current and past profits levels, and expected future earnings, and are negatively correlated with changes in the level of sales. Current income remains the critical determinant of corporate dividend policy 25 years after Linter's original survey.

Payout decisions have an impact but are also affected by the shareholders. Most straightforwardly distributing cash to shareholders increase their cash balance and hence relaxes their liquidity constraints. Most interestingly the decision to distribute cash may have a dynamic relationship with the properties of the stock prices and hence the liquidity of the stock in the market place (Gordon, 1963). Lintner (1956) suggested that dividend depends in part on the firm's current earnings and in part on the dividend for the previous year. $\mathrm{He}$ found that major changes in earnings with existing dividend rates are the most important determinants of the firm's dividend payout policy. He also found that firms tend to make periodic partial adjustments toward a target policy ratio rather than dramatic changes in policy. Fama and Babiak (1968) support Lintner's argument that managers increase dividends only after they are reasonably sure that they can permanently maintain them at the new level.

Dividend provides a reward in a sense to investors who have taken a risk by investing in the stock of a certain company. Income that is earned by the company is distributed to the shareholders, and frequently increases over time. They are normally paid on a consistent basis, such as quarterly (Banarjee, 2008). Companies that have a record of paying dividend are usually traded at premium versus those that do 
not. Investors in the company are thus provided cash flow without having to sell shares; therefore, traditionally, companies paying relatively high dividend have been purchased by those on a fixed income. Al-Malkawi (2007) managers base current dividend level on past dividend levels and current earnings and prefer dividend to be stable over time.

Lintner (1956) suggests that dividend depends in part on the firm's current earnings and in part on the dividend for the previous year. He finds that major changes in earnings with existing dividend rates are the most important determinants of the firm's dividend policy policies. He also finds that firms tend to make periodic partial adjustments toward a target policy ratio rather than dramatic changes in policy. Fama and Babiak (1968) support Lintner's argument that managers increase dividends only after they are reasonably sure that they can permanently maintain them at the new level.

\section{Methodology}

\subsection{Research Design}

Research design refers to a set of decisions that make up the master plan specifying the methods and procedures for collecting and analyzing the needed information (Mugenda \& Mugenda, 1999). The study therefore employed causal comparative research design. Causal comparative research design is a type of design in which the researcher attempts to identify cause-effect relationship among variables that cannot be manipulated (Kasomo, 2006). According to Mugenda and Mugenda (1999) the purpose of causal research is to identify the cause or causes of change in a variable or event. This design aided in exploring the effect that the independent variable has on the dependent variable and as a result enabled the researcher to determine whether liquidity has any effect on the dividend payout of a firm.

\subsection{Sampling Procedures and Sample Size}

Sampling procedure is the method a researcher uses to gather people, places or things to study (Kombo \& Tromp, 2006). It is a process of selecting a number of individuals or objects from a population such that the selected group contains elements of representative of the characteristics found in the entire group (Orodho, 2009). Purposive sampling procedure was used in the study to select the sample. Purposive sampling is a sampling technique that allows a researcher to use cases that have the required information with respect to the objectives of his or her study (Mugenda \& Mugenda, 1999). According to Kathuri and Pals (1993) in purposive sampling, the researcher picks only those who meet the purposes of the study. The suitability of purposive sampling is to pick the cases that are typically to the population being studied. The sample consisted of the firms that were listed consistently in NSE for five years (2008 to 2012). The companies that met the fulfilment of consistently paying dividends for five years in the period of 2008 to 2012 were considered. The firms whose complete information could not be obtained at the NSE during the five years were excluded from the sample and for this reasons only the firms that met the present criteria was selected, thus a sample of 30 firms. Table 1 shows the distribution of sampled firms in various sectors at the NSE.

Table 1. Distribution of Sampled Firms in Various Sectors at the NSE.

\begin{tabular}{lll}
\hline Sectors & Population & Sample (n) \\
\hline Agricultural & 7 & 7 \\
Automobiles and Accessories & 4 & 0 \\
Banking & 11 & 4 \\
Commercial and Services & 9 & 5 \\
Construction and Allied & 5 & 4 \\
Energy and Petroleum & 5 & 2 \\
Insurance & 6 & 2 \\
Investment & 3 & 0 \\
Manufacturing and Allied & 9 & 5 \\
Telecommunication and Technology & 1 & 1 \\
Growth and Enterprise Market & 6 & 0 \\
Total & 61 & 30 \\
\hline
\end{tabular}

Source: NSE Handbook 2013

\subsection{Data Collection Procedures}

Secondary data was extracted from the audited annual reports and financial statements of individual companies sourced from the NSE and the CMA. In order to determine the relationship that exists between liquidity and dividend payout of the quoted companies at the NSE, a period of five years (2008-2012) was considered since most companies consistently paid dividends within that period. Data collected was as per sectors of the individual sampled companies. The annual financial statement included the statement of comprehensive income and financial position.

\subsection{Data Analysis}

Mugenda and Mugenda (2005) describe data analysis as coding, categorizing, data entry, manipulation and summarization of data. Once the data was collected it was edited, organized and cleaned. Data was tested for linearity, normality, homoscedasticity and Collinearity to ensure that the assumptions of the regression model holds. It was accumulated in Ms excel and then exported to Statistical Package for Social Sciences (SPSS) for analysis. Descriptive statistics was used in the analysis through calculations of mean and standard deviation to measure and compare results. The coefficient of constant was obtained after applying advanced MS Excel and SPSS version. Student t-test was used to determine whether the slope and predictor variable coefficients are statistically significant at $5 \%$. Multiple linear regression was used to determine the nature and magnitude that exists between variables. Hypothesis was tested at 5\% level of significance to determine the relationship between liquidity and dividend pay-out. In order to identify the effect that the independent variable has on the dependent variable, the following regression model was used. Regression relationship between liquidity and dividend payout by Gill and 
Tibrewala (2010) model is as shown:

$$
\mathrm{DPO}_{\mathrm{i}, \mathrm{t}=} \beta_{\circ}+\beta_{1} \mathrm{P}_{\mathrm{i}, \mathrm{t}}+\beta_{2} \mathrm{C}_{\mathrm{i}, \mathrm{t}}+\beta_{3} \mathrm{WC}_{\mathrm{i}, \mathrm{t}}+\varepsilon_{\mathrm{i}, \mathrm{t}}
$$

Where: $D P O=$ Dividend pay-out; $P_{\mathrm{i}, \mathrm{t}}=$ Profitability; $C_{\mathrm{i}, \mathrm{t}}=$ Cash flow in year $\mathrm{t} ; W C_{\mathrm{i}, \mathrm{t}}=$ Working Capital in year $\mathrm{t} ; \beta_{0}$ $=$ Fixed individual effect (The variable that absorbs the independent variable); $\beta_{1}, \beta_{2}, \beta_{3}$, = Regression Co-efficient of Independent Variables; $\varepsilon_{i, t}=$ Error Term , $(\mathrm{i}=$ Firms and $\mathrm{t}=$ years)

\section{Empirical Results and Discussions}

\subsection{Descriptive Analysis}

Descriptive statistics of the variables used in research (depicted on Table 2) was done by the normality test to predict whether the data is normally distributed or not. Normality tests are used to determine whether a data set is well-modeled by a normal distribution to compute how likely an underlying random variable is to be normally distributed. The descriptive statistics is presented in Table 2.

Table 2. Descriptive Statistics.

\begin{tabular}{lllll}
\hline Variables & Minimum & Maximum & Mean & Std. Deviation \\
\hline DPO & 0.040 & 0.949 & 0.400 & 0.263 \\
ROE & 0.047 & 0.593 & 0.235 & 0.154 \\
Cr & 0.337 & 9.853 & 2.446 & 2.719 \\
$\ln$ EVA & 8.201 & 13.276 & 10.323 & 1.888 \\
\hline
\end{tabular}

The mean represents a generalization of the data. It suggests that for any given state the data values were on average. The mean for all the explanatory variables are within the maximum and minimum range. A set of data having extremely high or low data values, the mean tends to be pulled in the direction of outliers and therefore can misrepresent the data central tendency. From Table 2 the mean of dividend pay-out ratio (DPO) is 0.400 which represents the average DPO for all the firms at the NSE. ROE which shows the percentage of profits after tax to total equity has a mean of 0.235 which indicates the average of ROE (Return on Equity) for all firms at the NSE (Nairobi Stock Exchange). Working capital measured by current ratio has a mean of 2.446 which represents the average current ratio for all firms under study. Cash flows were measured by the natural logarithm of economic value added to make it linear and to reduce the error term have a mean of 10.323 which indicates the average of Economic value added (EVA) for all firms listed at the NSE. The mean values from Table 2 are not extremely high or low thus representation of the data central tendency. Standard deviation is a measure of dispersion and gives us a way to describe where any given data is located with respect to the mean. To determine the concentration of data around the mean the following bounds were created $\pm 1, \pm 2, \pm 3$ standard deviation. From Table 2 most of the data falls within these bounds which suggest that the data are concentrated around the mean thus the less spread or dispersion a data is likely to be.

\subsection{One-Sample Kolmogorov-Smirnov Test}

One Sample Kolmogorov-Smirnov test is used to test the normality of data since the study used the regression model and student t-test which are non parametric thus requires the data to be normal. Table 3 shows One-Sample Kolmogorov-Smirnov Test.

Table 3. One-Sample Kolmogorov-Smirnov Test.

\begin{tabular}{|c|c|c|c|c|c|}
\hline \multirow{2}{*}{$\mathbf{N}$} & & \multirow{2}{*}{$\begin{array}{l}\text { DPO } \\
30\end{array}$} & \multirow{2}{*}{$\begin{array}{l}\text { ROE } \\
30 \\
\end{array}$} & \multirow{2}{*}{$\begin{array}{l}\mathrm{Cr} \\
30 \\
\end{array}$} & \multirow{2}{*}{$\begin{array}{l}\text { In EVA } \\
30\end{array}$} \\
\hline & & & & & \\
\hline \multirow{2}{*}{$\begin{array}{l}\text { Normal } \\
\text { Parameters }^{\mathrm{a}, \mathrm{b}}\end{array}$} & Mean & 0.400 & 0.235 & 2.446 & 10.323 \\
\hline & $\begin{array}{l}\text { Std. } \\
\text { Deviation }\end{array}$ & 0.263 & 0.154 & 2.719 & 1.888 \\
\hline \multirow{3}{*}{$\begin{array}{l}\text { Most Extreme } \\
\text { Differences }\end{array}$} & Absolute & 0.192 & 0.222 & 0.323 & 0.237 \\
\hline & Positive & 0.192 & 0.222 & 0.323 & 0.237 \\
\hline & Negative & -0.092 & -.110 & -0.219 & -0.167 \\
\hline \multicolumn{2}{|c|}{ Kolmogorov-Smirnov Z } & 0.960 & 1.108 & 1.614 & 1.184 \\
\hline \multicolumn{2}{|c|}{ Asymp. Sig. (2-tailed) } & 0.315 & 0.172 & 0.011 & 0.121 \\
\hline
\end{tabular}

a. Test distribution is Normal.

b. Calculated from data.

Table 3 was used to test whether the data was normally distributed and this was achieved through a normal test. The values of mean and standard deviation of the variables prove that the data is normally distributed since the data is concentrated around the mean values thus less spread. The 2-tailed significant test is above the significant value of 0.05 thus the distribution of data is normal and that the data are different among the different companies listed at the NSE of the sample. The normality shows the companies tested by this study, their means and standard deviations. The extreme dividend payouts are presented by the normal test, which varies among the companies under study as indicated by the values of standard deviations and the extreme differences.

\subsection{Tests for the Assumptions of the Linear Regression Model}

\subsubsection{Multi-Collinearity Test}

Multi-Collinearity was measured by variance inflation factor (VIF) or using tolerance. Variance inflation factor refers to a situation where two or more independent variables are highly correlated value $>0.9$ hence leading to Multi-Collinearity problem Lee 1993 as sighted in (Jingyu, 2003). According to Besley 1980 as sighted in (Jingyu, 2003) researchers have used $\mathrm{VIF}=10$ as critical value rule of thumb to determine whether too much correlation. The VIF values in Table 12 below are less than 10 so there was no Multi-Collinearity problem. If Multi-Collinearity increases, the regression coefficient can fluctuate from sample to sample hence complicating interpretation of the coefficient as an indicator of relative importance of predicting variables (Cooper \& Schindler, 2003).

Tolerance is an indication of the percent of variance in the predictor that cannot be accounted for by other predictors, hence very small values indicate that a predictor is redundant, and the values that are less than $10 \%$ may merit further 
investigation. From table 12 below the tolerance value of ROE is 0.846 . If ROE is the dependent variable against current ratio and EVA as the independent variable will be 1 less 0.846 which is equal to $0.154 .15 .4 \%$ variation can be explained by current ratio and the natural logarithm of Economic value added (EVA) which is now more than $10 \%$ thresholds and thus the absence of Multi Collinearity. Multicollinearity was also tested using Eigen values and the condition index. An Eigen value indicates the importance of variables on parameters in the model. A condition index of less than 10 implies that there is no presence of multi collinearity and thus the one with the highest condition index assists in identifying the selection model. A summary of Eigen values and condition index is provided in Table 4.

Table 4. Collinearity Diagnostics.

\begin{tabular}{lllllll}
\hline \multirow{2}{*}{ Dimension } & $\begin{array}{l}\text { Eigen } \\
\text { value }\end{array}$ & $\begin{array}{l}\text { Condition } \\
\text { Index }\end{array}$ & \multicolumn{4}{l}{ Variance Proportions } \\
\cline { 5 - 7 } & 3.416 & 1.000 & 0.00 & 0.02 & 0.02 & 0.00 \\
\hline 1 & 0.386 & 2.974 & 0.01 & 0.02 & 0.69 & 0.00 \\
2 & 0.187 & 4.273 & 0.02 & 0.95 & 0.02 & 0.01 \\
3 & 0.011 & 7.706 & 0.97 & 0.02 & 0.27 & 0.98 \\
4 & & &
\end{tabular}

In Table 4 EVA had the highest contribution index of 7.706 while ROE had the lowest condition index of 2.974 , thus the constant is contributing $97 \%$, ROE $2 \%$, current ratio $27 \%$ and EVA is contributing 98\%. According to the Eigen values the constant is the most significant followed by ROE, current ratio and the natural logarithm of EVA is the least significant.

\subsubsection{Homoscedasticity}

Homoscedasticity refers to the assumptions that dependent variable(s) exhibit equal levels of variance across the range of independent variable(s) (Hair. \& Tatham, 2010). The test of homoscedasticity was needed because the variance of the dependent variable being explained in the dependence relationship should not be concentrated in only a limited range of the independent values (Hair. \& Tatham, 2010). The standard errors of the estimators will be biased if heteroscedasticity do exist. The residuals plot indicated that the clusters of points are distributed approximately the same width all over the average residual hence the residual plot is rectangular, with a concentration of points along the centre. Thus this does not violate the assumption of homoscedasticity.

\subsubsection{Test for Heteroscedasticity}

A test for heteroscedasticity is made to test for variances in residuals in the model used. Heteroscedasticity does not cause ordinary least squares coefficients estimates to be biased, although it can cause ordinary least square estimates of the variance of the coefficients to be biased, thus regression analysis using heteroscedasticity data will provide an unbiased estimate for the relationship between the predictor variable and the outcome but the standard errors will be biased leading to biased inference. In this study heteroscedasticity was checked with visual comparisons. It was found that there was no heteroscedasticity observed in the regression analysis. The heteroscedasticity scatter shows a clear scatter plot and this means that the standard deviations of the residuals are reliable.
It can therefore be concluded that since heteroscedasticity is not apparent then the model represent a realistic view of liquidity on dividend payout.

\subsection{Correlation}

\subsubsection{Correlations Between Profitability and Dividend Payout}

Pearson correlation was used to establish the relationship between profitability and dividend payout as depicted in Table 5.

Table 5. Correlations between Profitability and Dividend Payout.

\begin{tabular}{llll}
\hline & & DPO & ROE \\
\hline \multirow{4}{*}{ DPO } & Pearson Correlation & 1 & \\
& Sig. (2-tailed) & & \\
& N & 30 & \\
\multirow{4}{*}{ ROE } & Pearson Correlation & $0.556^{*}$ & 1 \\
& Sig. (2-tailed) & 0.004 & \\
& N & 30 & 30 \\
\hline
\end{tabular}

Correlation is significant at the 0.05 level (2-tailed).

Table 5 provides the Pearson correlation matrix for the variables used in the analysis. Pearson's correlation determines the relationship between profitability and dividend pay-out. The results were that profitability which was measured by ROE has a positive relationship with the dividend pay-out (DPO) and is significant at $95 \%$ confidence level. The statistic is 0.556 and the $\mathrm{P}$ value is 0.004 which is less than 0.05 thus significant at $95 \%$ confidence level. This indicates that profitable firms are likely to increase the dividend pay-out and thus they move in the same direction. The positive correlation could be because as profits of the firm increases dividends also increase, this is inconsistent with (Anupam, 2012) who found that profitability of the firms as measured by ROE has negative relationship with dividend pay-out.

\subsubsection{Correlations between Cash Flows and Dividend Payout}

Pearson correlation was used to establish the relationship between cash flows and dividend payout depicted in Table 6 .

Table 6. Correlations between Cash Flows and Dividend Payout.

\begin{tabular}{llll}
\hline & & DPO & In EVA \\
\hline \multirow{4}{*}{ DPO } & Pearson Correlation & 1 & \\
& Sig. (2-tailed) & & \\
& $\mathrm{N}$ & 30 & \\
& Pearson Correlation & $0.892^{*}$ & 1 \\
& Sig. (2-tailed) & 0.000 & \\
& $\mathrm{~N}$ & 30 & 30 \\
\hline
\end{tabular}

Table 6 provides the Pearson correlation matrix for the variables used in the analysis. Pearson's correlation determines the relationship between cash flows and dividend pay-out. The results were that cash flows which were measured by economic value added (EVA) has a positive relationship with the DPO and are significant at $95 \%$ confidence. The test statistic is 0.892 and the $\mathrm{P}$ value is 0.000 which is less than 0.05 thus an increase in free cash flows will consequently lead to an increase in 
dividend pay-out. A poor in flow of cash will constraint the firm in paying dividends thus resulting in paying low or no dividends, this is consistent with (Amidu \& Abor ,2006) who found out that cash flows have a positive relationship with the dividends paid.

\subsubsection{Correlations between Working Capital and Dividend Payout}

Table 7. Correlations between Working Capital and Dividend Payout.

\begin{tabular}{llll}
\hline & DPO & Cr \\
\hline \multirow{3}{*}{ DPO } & Pearson Correlation & 1 & \\
& Sig. (2-tailed) & & \\
& N & 30 & 1 \\
& Pearson Correlation & $0.717^{*}$ & 1 \\
& Sig. (2-tailed) & 0.000 & 30 \\
\hline
\end{tabular}

Correlation is significant at the 0.05 level (2-tailed). Put this statement below table 7. (Eg see table 8 below)
Pearson correlation was used to establish the relationship between working capital and dividend payout depicted in Table 7

Table 7 provides the Pearson correlation matrix for the variables used in the analysis. Pearson's correlation determines the relationship between working capital and the dividend payout. The results were that working capital measured by current ratio has a positive relationship with the dividend pay-out (DPO) and is significant at $95 \%$ confidence level. Test statistic is 0.717 and the $\mathrm{P}$ value is 0.000 which is less than 0.05 thus an increase in current ratio will consequently lead to an increase in dividend pay-out. The more the current asset a firm has the more is likely to pay high dividends and thus working capital is positively related with the dividend pay-out. The summary of the correlations between independent and dependent variables is shown in Table 8.

Table 8. Summary of Correlations.

\begin{tabular}{|c|c|c|c|c|c|}
\hline & & DPO & ROE & $\mathrm{Cr}$ & In_EVA \\
\hline \multirow{3}{*}{ DPO } & Pearson Correlation & 1 & $0.556^{*}$ & $0.717^{*}$ & $0.892^{*}$ \\
\hline & Sig. (2-tailed) & & 0.004 & 0.000 & 0.000 \\
\hline & $\mathrm{N}$ & 30 & 30 & 30 & 30 \\
\hline \multirow{3}{*}{ ROE } & Pearson Correlation & $0.556^{*}$ & 1 & 0.331 & 0.366 \\
\hline & Sig. (2-tailed) & 0.004 & & 0.106 & 0.072 \\
\hline & $\mathrm{N}$ & 30 & 30 & 30 & 30 \\
\hline \multirow[t]{2}{*}{$\mathrm{Cr}$} & Sig. (2-tailed) & .000 & .106 & & 0.002 \\
\hline & $\mathrm{N}$ & 30 & 30 & 30 & 30 \\
\hline \multirow{3}{*}{ ln EVA } & Pearson Correlation & $0.892^{*}$ & 0.366 & $0.592^{*}$ & 1 \\
\hline & Sig. (2-tailed) & .000 & .072 & 0.002 & \\
\hline & $\mathrm{N}$ & 30 & 30 & 30 & 30 \\
\hline
\end{tabular}

Correlation is significant at the 0.05 level (2-tailed).

\subsection{Test for the Significance of the Regression Coefficients}

Coefficients of the independent variables were tested using student $t$ - test to determine whether they are significant at 5\%. A summary of the significance of the regression coefficients is provided in Table 9.

Table 9. Significance of the Coefficients.

\begin{tabular}{llllll}
\hline \multirow{2}{*}{ Model } & & \multicolumn{2}{l}{$\begin{array}{l}\text { Unstandardized } \\
\text { Coefficients }\end{array}$} & $\begin{array}{l}\text { Standardized } \\
\text { Coefficients }\end{array}$ & \multirow{2}{*}{ Sig. } \\
\cline { 3 - 5 } & B & Std. Error & Beta & \\
\cline { 3 - 5 } & (Constant) & -0.700 & 0.116 & & 0.000 \\
1 & ROE & 0.397 & 0.131 & 0.232 & 0.006 \\
& Cr & 0.024 & 0.009 & 0.250 & 0.010 \\
& ln EVA & 0.092 & 0.012 & .659 & 0.000 \\
\hline
\end{tabular}

Standardized coefficients are the estimates resulting from an analysis performed on variables that have been standardized so that they have variances of 1 . Unstandardized coefficients indicate the average change in the independent variable associated with a one unit change in the dependent variable, statistically controlling for the other independent variable, thus the unstandardized coefficients from Table 9 was used in this study.

\subsubsection{Effect of Profitability on the Dividend Payout}

Hypothesis was tested using t- test to determine the acceptance or rejection of the hypothesis stipulated. Profitability was measured by ROE and the results indicate that profits have a positive effect on the firms' dividend payout depicted in Table 9. A unit increase in ROE result in 0.397 increase in dividend payout ratio. ROE has a $\mathrm{P}$ value of 0.006 which is less than 0.05 and thus statistically significant at $5 \%$. This resulted to the failure to accept the null hypothesis that profitability has no significant effect on the firms' dividend pay-out decisions. The interval of ROE variable is not crossing zero thus the coefficient is statistically significant therefore as the profits of the firm increases the dividend payout of a firm also increases. This is consistent with Ahmed and Javid (2009) who found that profitable firms with more stable net earnings can afford larger free cash flow and therefore pay larger dividends. They noted that market liquidity also has positive impact on dividend pay-out policy, thus firms with higher rate of return on equity paid higher dividends than firms with lower return on equity. 


\subsubsection{Effect of Cash Flows on the Dividend Payout}

Hypothesis was tested using $\mathrm{t}$ - test to determine the acceptance or rejection of the hypothesis stipulated. Cash flows were measured by the logarithm of EVA and the results indicate that cash flows have a positive effect on the firms' dividend payout as depicted in Table 9. A unit increase in EVA result in 0.092 increase in dividend payout ratio. EVA has a $\mathrm{P}$ value of 0.010 which is less than 0.05 and thus statistically significant at $5 \%$. This resulted to the failure to accept the null hypothesis that cash flows have no significant effect on the firms' dividend pay-out decisions. The interval of EVA variable is not crossing zero thus the coefficient is statistically significant thus as the cash flows of the firm increases the dividend payout of a firm also increases. The result concurs with Okpara (2010) who found that cash dividend payment had a direct relationship with operating cash flows. The study revealed that firms with free cash flow paid higher dividends. The more free cash flows a firm have the higher the dividend pay-out of the firm.

\subsubsection{Effect of Working Capital on the Dividend Payout}

Hypothesis was also tested using t- test to determine the acceptance or rejection of the hypothesis stipulated. Working capital was measured by the current ratio and the results showed that working capital has a positive effect on the firms dividend payout as depicted in Table 9. A unit increase in current ratio result in 0.024 increase in dividend payout ratio. Current ratio has a $\mathrm{P}$ value of 0.000 which is less than 0.05 and thus statistically significant at $5 \%$. This resulted to the failure to accept the null hypothesis that working capital has no significant effect on the firms' dividend pay-out decisions The interval of current ratio variable is not crossing zero thus the coefficient is statistically significant therefore as the current assets of the firm increases the dividend payout of a firm also increases. This result is inconsistent with Okpara (2010) who observed that current ratio (liquidity) and previous years dividends exerts a negative influence on the dividend pay-out ratio in Nigeria's firms, thus liquidity does not affect the dividend pay-out of a firm.

\subsection{Model Specification}

This was used to identify the cause-effect relationship between independent and dependent variables. Table 10 provides a summary of the model specification.

Table 10. The Goodness of Fit.

\begin{tabular}{lllll}
\hline R & R Square & $\begin{array}{l}\text { Adjusted } \\
\text { R Square }\end{array}$ & $\begin{array}{l}\text { Std. Error of } \\
\text { the Estimate }\end{array}$ & Durbin-Watson \\
\hline $0.946 \mathrm{a}$ & 0.896 & 0.881 & 0.091 & 0.899 \\
\hline
\end{tabular}

Table 10 is the model summary with the value of $\mathrm{R}$ square as 0.896 implying that about $89.6 \%$ of variation can be explained by the independent variable or can be accounted for in the dependent variable DPO and $10.4 \%$ can be accounted for by other factors that are not within the control of the researcher. The regression results indicates that all the independent variables are significant in affecting the dividend payout of firms listed on NSE. Adjusted R squared is the coefficient of determination which explains the variation in the dependent variable due to changes in the independent variable, from the findings in the above table the value of adjusted $\mathrm{R}$ square was 0.881 an indication that there was variation of $88.1 \%$ on the dividend payout ratio of companies listed at the NSE due to changes in the independent variable which are return on equity, economic value added and the current ratio. The regressors for this study are ROE, current ratio and EVA.

Table11 was used to test whether the predictors have significant effect on the dependent variable for instance if one predictor is dropped from the model the dependent variable will be significantly affected since the $P$ value is less than 0.05 thus statistically significant. The $F$ value from Table 11 is significant at 5 per cent level $(\mathrm{F}=60.136, \mathrm{P}<$ $0.05)$ showing the applicability of the overall model.

Table 11. The Overall Significance.

\begin{tabular}{lllll}
\hline & Sum of Squares & Mean Square & F & Sig. \\
\hline Regression & 1.487 & 0.496 & 60.136 & $0.000^{\mathrm{b}}$ \\
Residual & .173 & 0.008 & & \\
Total & 1.660 & & & \\
\hline
\end{tabular}

\subsection{Regression Equation}

The variables of the study are related using a stochastic multiple linear regression equation of the form below:

$$
D P O=-0.7+0.397 R O E+0.024 C r+0.092 E V A+\varepsilon_{i, t}
$$

The regression equation above reveals that holding ROE, current ratio and EVA to a constant zero, dividend payout ratio for the firms listed at the NSE would stand at -0.700 , thus a unit increase in ROE would lead to an increase in the dividend payout ratio of the company by a factor of 0.397 , a unit increase in current ratio of the company would lead to an increase in the dividend payout ratio of the company by factors of 0.024 , a unit increase in EVA would lead to an increase in the dividend payout ratio of the firm by factors of 0.092. The coefficients of ROE, current ratio and EVA are $0.397,0.024$ and 0.092 respectively as depicted in Table 9. The coefficients of the independent variables were tested using t-test to determine their significance level. The $\mathrm{P}$ values calculated for ROE, current ratio and EVA are less than 0.05 and thus significant at 5\%. The intervals of the independent variable coefficients are not crossing zero both in the upper and lower bound thus statistically significant for the model. The expected value of the error term was equal to zero hence the error term was not include in the regression equation.

\section{Conclusions and Recommendations}

\subsection{Conclusions}

The study found out that there exists a positive effect of liquidity on dividend pay-out. As the level of liquidity 
increases, the dividends paid out level do also increase and vice versa. From the data collected, analyzed and conclusion made thereof showed that, firms maintain high liquidity thresholds in order to mitigate any likelihood of financial distress and they do this by embracing the best business practices through optimum working capital management. It also showed that firms maintain high liquidity levels in order to settle dividends as they fall due. The study also revealed that profitability plays a major role in dividend pay-out and consequently the companies which posted higher profits translated this to higher dividends paid out to investors. Profitability of a firm is an indicator of a firms' capacity to pay dividends and thus higher profits declared signals higher dividend pay-out. This study concurs with the findings of previous empirical studies done on liquidity. Ahmed and Javid (2009), Mahapatara and Sahu (1993) in their respective studies concurred that liquidity among other factors had positive impact on the dividends pay out and therefore firms with higher liquidity can afford to pay dividends without resorting to borrowing.

\subsection{Recommendations}

Based on the findings in this study, the following recommendations are made:

i. Managers of listed firms should aim at increasing the return on equity, ensure that the cash flows are adequate to the business which to the opinion of the management would yield high profits this will make the firm to have high dividend payout which will improve investors' confidence in the firm hence value of the firm.

ii. Firms should regularly review their dividend payout policy since it affects the ability of the firm to attract investors. It is also important for the firms to carry out a follow up survey to establish how the shareholders feel about the payout policy in place.

iii. Firms should ensure profits of the firm are stable, cash flows freely flow into the firm and working capital is efficiently managed so as to increase the firms' dividend payout since an optimum dividend payout ratio maximizes the shareholders wealth.

\section{Acknowledgement}

I would like to thank God the almighty through whose grace has seen me through this course. My sincere gratitude goes to my parents $\mathrm{Mr}$ and Mrs George Olang' and all those who contributed immensely in one way or the other towards the completion of this research papert. Special thanks to my supervisors James Mwangi and Henry Kimathi, for their encouragement, guidance, wisdom, support and constructive criticism given during the research which enabled me to complete this project on time. I am also indebted to Galo for his encouragement, positive criticism, corrections and moral support toward completion of this paper.

\section{References}

[1] Ahmed, H. \& Javid, A. (2009). The Determinants of Dividend Policy in Pakistan (Evidence from Karachi Stock Exchange, Non Financial Listed Firms); International Research Journal of Finance and Economics; ISSN 1450-2887 Issue 25.

[2] Albercht, W. \& Stice, J. (2008). Financial Accounting. Manson,OH: Thomson/South-Western.

[3] Alli, K.; Khan, A. \& Ramirez, G. (1993). Determinants of Dividend Policy: A Factorial Analysis. Finance Review 28, 523-47.

[4] Al-Malkawi, H. (2007). Determinants of Corporate Dividend Policy in Jordan: An Application of the Tobit Model . Journal of Economics and Administrative Sciences 23(2) , 44-70.

[5] Amidu, M. \& Abor, J. (2006). Determinants of Dividend Policy Ratios in Ghana. Journal of Risk Finance; 7: 136-45.

[6] Anil, K. \& Kapoor, S. (2008). Determinants of Dividend Policy Ratios: A Study of Indian Information Technology Sector. International Research Journal in Finance Economics 15: $1-9$.

[7] Anupam, M. (2012). An Empirical Analysis of Determinants of Dividend Policy - Evidence from the UAE Companies. Global Review of Accounting and Finance Vol. 3.No. 1. 18-31.

[8] Baker, M. \& Wurgler, J. (2004). A Catering Theory of Dividends. Journal of Corporate Finance Vol. 2. No. 2. 5-12.

[9] Banerjee, B. (2008). Fundamentals of Financial Management. New Delhi: Prentice-Hall.

[10] Bangkok Bank. (2008). Annual report. Bangkok: Bangkok Bank.

[11] Banerjee, S.; Gatchev, V. \& Spindt, P. (2007). Stock Market Liquidity and Firm Dividend Policy. Journal of Financial and Quantitative Analysis, 42(2), 369-384.

[12] Besley, S. \& Brigham, E. (2008). Essentials of Managerial Finance. Manson: OH: Thomson/South-Western.

[13] Brealey, R. \& Myers, S. (2002). Financing and Risk Management. New York: McGraw-Hill.

[14] Cooper, D. \& Schindler, P. (2003). Business Research Methods (8ed.). Boston: MA: McGraw Hill.

[15] Fama, E. F. \& Babiak, H. (1968). 'Dividend Policy An Empirical Analysis'. Journal of American Statistical Association, 63, 1132-1161.

[16] Eljelly, A.M. (2004). Liquidity, Profitability Trade-off: An Empirical Investigation in an Emerging Market. International Journal of Commerce and Management; 14:46-51.

[17] Gill, B \& Tibrewala, R. (2010). Stock Market Liquidity and Firm dividend policy. The Open Business Journal, Vol. 3, pp $8-14$.

[18] Gordon, M. J. (1963). The investment, Financing and Valuation of Corporation.Irwin: McGraw Hill Co.

[19] Hair, B. \& Tatham, R. (2010) Multivariate Data Analysis (7ed). New York: Pearson Publishers. 
[20] Kasomo, D. (2006). Research Methods in Humanities and Education. Njoro: Egerton University Press.

[21] Kathuri, J. \& Pals, A. (1993). Introduction to Educational Research.Njoro: Egerton University Educational Media Centre.

[22] Kombo, D. \& Tromp, D. (2006). Guidelines to Proposal and Thesis Writing. Nairobi: Pauline Publishers Africa.

[23] Lintner, J. (1956). The Distribution of Incomes of Corporations among Dividends, Retained Earnings and Taxes. American Economic Review, 46, 97-113.

[24] Lintner, J. (1962). Dividends, Earnings, Leverage, Stock Prices and Supply of Capital to Corporations. The Review of Economics and Statistics 64, 243-269.

[25] Litzenberger, R. H. \& Ramaswamy K. (1979). The Effect of Personal Taxes and Dividends on Capital Asset Prices, Journal of Financial Economics 7, 163-95.

[26] Liu, S. \& Hu, Y. (2005). Empirical Analysis of Cash Dividend Payment in Chinese Listed Companies. Nature and Science, $3(1), 65-70$

[27] Mahapatara, R. P. \& Sahu, P.K (1993).Analysis of Determinants of Corporate Dividend Behaviour in India, an Economic Analysis Decision 20. 1-22.

[28] Miller, M. H. \& Rock, K. (1985). Dividend Policy under Asymmetric Information. Journal of Finance, 40, 1031-1051.

[29] Modigliani, F. \& Miller, M. (1961). Dividend Policy, Growth, and the Valuation of Shares. The Journal of Business, 34(4), 411-428.

[30] Mugenda, O. M. \& Mugenda, A.G. (2005). Research Methods: Quantitative and Qualitative Approaches. Nairobi: Acts press.

[31] Nikolai, L. A.; Bazley, D.J. \& Jones, J. P. (2010). Intermediate Accounting (11ed.). Manson, Australia: South-Western.

[32] NSE, (2009). NSE Handbook. Retrieved on $17^{\text {th }}$ December 2009 from http:// www.nse.co.ke.

[33] NSE, (2010). NSE Handbook. Retrieved on $20^{\text {th }}$ December 2009 from http:// www.nse.co.ke.

[34] NSE, (2011). NSE Handbook. Retrieved on $31^{\text {st }}$ December 2009 from http:// www.nse.co.ke.
[35] NSE, (2012). NSE Handbook. Retrieved on $22^{\text {nd }}$ December 2009 from http:// www.nse.co.ke.

[36] NSE, (2013). NSE Handbook. Retrieved on $23^{\text {rd }}$ December 2009 from http:// www.nse.co.ke.

[37] Okpara, G. C. (2010). Diagnosis of the Determinants of Dividend Pay-Out Policy in Nigeria: Factor of Analytical Approach. American Journal of Scientific Research ISSN 1450-223X Issue 8; PP 57-67.

[38] Orodho, J. (2009). Elements of Education and Social Science Research Methods. Maseno: Kanezja Publishers.

[39] Pandey, I. (2005). Financial Management. New Delhi: Vikas Publishing House.

[40] Ross, S. A.; Westerfield, R. W. \& Jordan, B. D. (2011). Fundamentals of Corporate Finance $\left(7^{\text {th }}\right.$ ed.). Irwin: Mc-Graw Hill.

[41] Rozeff, M. S. (1982). Growth, Beta and Agency Costs as Determinants of Dividend payout Ratios, The Journal of Financial Research 5, 249-259.

[42] Scott, D. L. (2003). An A to Z Guide to Investment Terms for Today's Investor. Journal of Financial Economics, 12,230-250.

[43] Schneeman, A. (2010). The Law of Corporations and other Business Organisations. Clifton Park, New York: Delmar Cengage Learning.

[44] Sharan, V. (2009). Theories Explaining Fundamentals of Financial Management $\left(2^{\text {nd }}\right.$ ed). Delhi, India: Pearson Education.

[45] Walter, J. (1963). Dividend Policy: Its Influence on the Value of the Enterprise. Journal of Finance, 18 (2), 280-291.

[46] Watson, D. \& Head, A. (2007). Corporate Finance: Principles and Practice $\left(4^{\text {th }}\right.$ ed). New York: Pearson Education.

[47] Weiner, E. (2006). The New Liquidity Paradigm: Focus on Working Capital. Journal of Financial Economics, 32, 145 160.

[48] Weston, F. \& Brigham, E. (1986). Management Finance $\left(9^{\text {th }}\right.$ Ed). New York: The Dryden Press. 